\title{
Eclectic Traditional Value Hub Model or four-in-one: An Innovative Booster of Community Quadriliteracy among Adults in Rwandan Rural Communities
}

Niyibizi Epimaque ${ }^{a}$, Niyomugabo Cyprien ${ }^{a}$, Ngarukiye Valens ${ }^{a}$, Uwizeyemariya Aloysie ${ }^{a}$, Yanzigiye Beatrice $^{\mathrm{b}}$, Tabaro Cyprien ${ }^{\mathrm{a}}$, Mukamana Helene ${ }^{\mathrm{a}}$ and Mutarutinya Vedaste ${ }^{\mathrm{a}}$ ${ }^{a}$ School of Education, University of Rwanda - College of Education, Rwanda; ${ }^{b}$ Confucius Institute, University of Rwanda

ISSN: 2788-6298

DOI: https://doi.org/10.35293/tetfle.v2i1.93

\begin{abstract}
Various studies on literacy have been conducted worldwide, but there is paucity of studies that explored adult literacy from the perspectives of African traditional values. Many African communities, including Rwanda, still experience a low level of literacy in the $21^{\text {st }}$ century. As a contribution to address this literacy gap, an innovative model coined "Eclectic Traditional Value Hub Model" is being implemented in selected Rwandan rural communities to promote quadriliteracy, community literacy and digital literacy among adults with limited literacy. The newness of this model is twofold: firstly, it draws from a range of African and Rwandan traditional values; secondly, it boosts parallel literacy practices in four languages, namely Kinyarwanda, English, French and Kiswahili, by which it is described as "Four-in-One". This study reports on one year's implementation of this model, exploring its level of success in accelerating quadriliteracy and community digital literacy and numeracy among Rwandan communities. Participants include University of Rwanda lecturers who initiated the model, graduates from secondary schools who are literacy trainers in their local communities and trainees who are citizens with limited literacy including motorists, street vendors, small-sized business people and others who strive to uplift their literacy levels. The successful stride of this model is that about ten thousand community members from Eastern province are accelerating their literacy practices through translingual and cross-lingual practices. We recommend the application of this model to other African settings with more African traditional values and assess its impact in minimising the high illiteracy rate reported in various corners of Africa.
\end{abstract}

Keywords: Community literacy; quadriliteracy, four-in-one; eclectic model, Rwanda, 4-in-1

CONTACT: Epimaque Niyibizi niyibizi.epimaque1973@gmail.com eniyibizi@yahoo.fr

This work is licensed under a Creative Commons Attribution 4.0 International License. 
Volume 2, 2020

\section{Introduction}

This paper reports on the conceptualisation and implementation of an innovative model coined "Eclectic Traditional Value Hub Model or Four-in-One" which was developed from a literacy project, initiated by lecturers from the University of Rwanda - College of Education, for their community outreach activities. The paper is both descriptive and empirical in nature, because it displays the description of the 'four-in-one' literacy model, which was initiated and implemented to boost quadriliteracy and digital literacy among rural communities in Rwanda. The paper is empirical as well because data was collected through assessment of the participating trainees' oral and written performance in four languages, namely English, French, Kiswahili and Kinyarwanda, altogether; followed by a questionnaire and interviews with the participants.

Multiliteracies which include quadriliteracy and digital literacy, are significant skills needed in the $21^{\text {st }}$ century. Such skills are in line with the theme of 2019 UNESCO International Literacy Prize, which is 'Literacy and Multilingualism'. This theme fits perfectly with the implementation of our model which aims at promoting quadrilingual literacy, that is literacy and numeracy in four languages. More specifically, the model stemmed from a literacy project which is being implemented in selected Rwandan rural communities to promote community literacy and digital literacy among adults with limited literacy in four official languages used in Rwanda, namely Kinyarwanda, English, French and Kiswahili. In this paper, literacy is viewed from Seligmann's (2012: 318) perspective as "the ability to read and write" or "the uses of reading and writing to achieve purposes in the context of use". In this regard, the model is being implemented in Rwanda, a country of thousand hills, located in the heart of Africa, towards East Africa, as indicated on the map in Figure 1. 
Volume 2, 2020

Figure 1

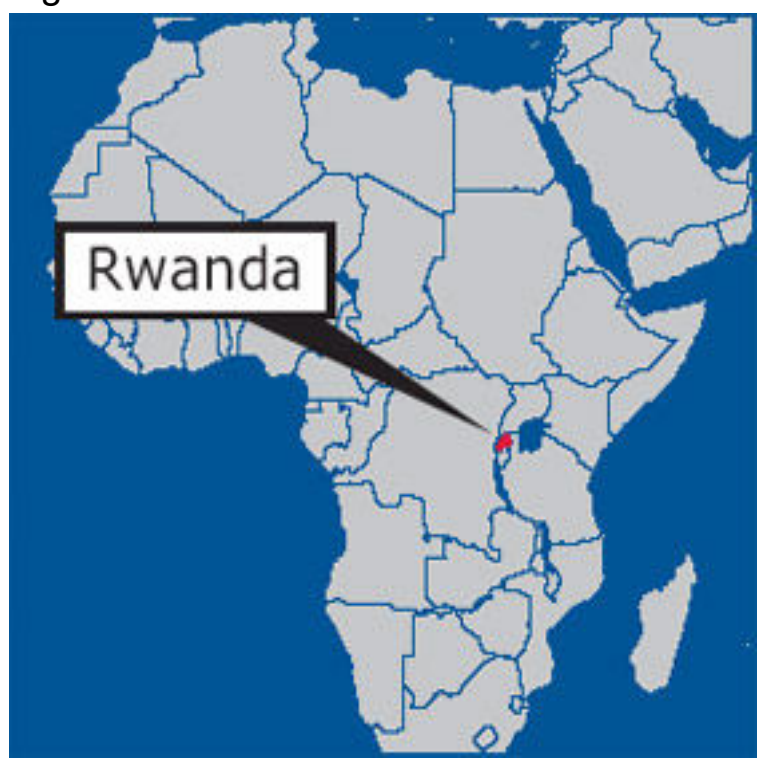

Source: http://minaloc.gov.rw

CONTACT: Epimaque Niyibizi niyibizi.epimaque1973@gmail.com eniyibizi@yahoo.fr 


\section{Contextual background on quadriliteracy in Rwanda}

The global context and the African continent perspective including the Rwandan reality, show that community literacy needs to be boosted. Our literacy model is relevant and useful to the individual community members and the societal needs at large. As evidence of the literacy rate in Rwanda, the 2012 National Population Census revealed that $29.4 \%$ of the total Rwandan population are non-literate in any language, while only $7 \%$ of the population are bilingual (i.e. literate in both Kinyarwanda and English) and 6\% trilingual (i.e. literate in Kinyarwanda, English and French) (MINECOFIN, 2014, p.45-49). The percentage of people who speak Kinyarwanda is $99.4 \%$. However, in 2012 only $67.7 \%$ of Rwandans aged 15 and beyond are literate in Kinyarwanda, and 14.7\% are literate in English (up from 1,9\% in 2002). Similarly, Rwandan people aged 15 and beyond who are literate in French in 2012 are $11.4 \%$ of the population, from 3,9\% in 2002; while Rwandan people aged 15 and beyond who were literate in Kiswahili were 3.7\% in 2012 from 3,0\% in 2002 (MINECOFIN, 2005; MINECOFIN, 2014). The proposed literacy model might have an impact in boosting quadriliteracy as it is reflected in its design, delivery, management, as well as in the monitoring and evaluation of its effectiveness, after one year of its implementation.

This paper, therefore, aims at presenting an innovative model coined "Four Languages in One Literacy Session" (Four-in-One) or "Eclectic Traditional Value Hub Model", together with its impact and effectiveness in boosting Community Literacy and digital literacy among the adults with limited literacy in the Rwandan multilingual setting, where four languages (Kinyarwanda, English, French and Kiswahili) are used. Such a model is applied to the Rwandan linguistic landscape, which is described by various researchers (Munyankesha, 2004; LeClerc, 2008; Samuelson \& Freedman, 2010; Rosendal, 2009; Sibomana, 2015; Niyibizi, 2015; Niyibizi, 2016; Niyibizi, Sibomana, Niyomugabo, Yanzigiye, Amini-Ngabonziza \& Perumal, 2018) as a multilingual but endoglossic country, to mean that four languages are officially recognised, with Kinyarwanda spoken by an overwhelming majority of the population (99.4\%).

It is within this context and background that the project reported in this paper strives to promote quadriliteracy among adults in Rwandan rural communities, enabling them to communicate with foreigners who study and work at the University of Rwanda's College of Education, located in Kayonza District. The increase of their literacy and numeracy skills would help them interact and earn money from all citizens of their community, including foreigners who buy items from them, transport them on motorcycles or work for them. The digital literacy skills would also help them to appropriately use their mobile phones and have access to e-banking, e-trading, e-health or e-agriculture services for a better-quality life. Hence, the focus on the implementation of the project and its effectiveness, as indicated in the next section.

CONTACT: Epimaque Niyibizi niyibizi.epimaque1973@gmail.com eniyibizi@yahoo.fr This work is licensed under a Creative Commons Attribution 4.0 International License. 


\section{Overall aim and contribution of the study}

This paper aims at promoting quadriliteracy and community literacy, with a particular focus on out-of-school literacy and numeracy, as well as digital literacy among adults living in African rural communities, specifically in Rwanda. The paper has a multidisciplinary nature that covers language education, literacy and numeracy, based on cultural practices and basic digital tools, all aiming at promoting community literacy among African citizens, including Rwandans, and informing the world on innovative practices.

The contribution of the paper is that this study stemmed from a literacy project which was implemented in selected rural communities in Rwanda, a country located at the heart of Africa, towards East Africa, as mentioned in the introduction and the background. The ultimate aim of the study and the project is to bridge language and scientific literacy gaps that hinder people with limited literacy from addressing both individual and societal needs as far as economic development is concerned. This is not only a Rwandan issue but an African and a global concern as well. The literacy practices reported in this paper targeted adults aged beyond fifteen, to minimise illiteracy among the African rural communities. Hence, the paper is aligned with the Rwandan vision of achieving national economic targets through citizen's education for their competencies (competence-based economy) (MINEDUC, 2018), which is also linked with the Rwandan aspiration for Vision 2050. This is also aligned with Sustainable Development Goals (SDGs), particularly Goal 4 of the 17 SDGs, which reads as to 'Ensure inclusive and equitable quality education and promote lifelong learning opportunities for all', also presented as Sustainable Development Goal two: 'promoting well-being for all at all ages' and Goal four: 'promoting lifelong learning opportunities for all' (United Nations, 2019).

The paper contributes in responding to some reported issues such as illiteracy of some Rwandan community members (MINECOFIN, 2014) and limited proficiency in languages among the educated community (Muhizi, 2014; Peason, 2014, Kagwesagge, 2012, Sibomana, 2015; Nzitabakuze, 2012; Niyibizi \& Niyomugabo, 2018). Illiteracy and limited proficiency in languages is not only a Rwandan challenge but a global one (Fretwell \& Colombano, 2000; Baker, 2006; Iwashita, Brown, McNamara \& O’Hagan, 2008).

Another contribution of this paper is that it has developed a grounded theory, which we have coined "Eclectic Traditional Value Hub Model or 'four-in-one' Literacy Model". The implementation of this literacy model promoted not only quadriliteracy but also digital literacy, especially the use of cell phones while practising literacy and numeracy, which promotes distance learning among adult citizen living in the Rwandan rural communities. This paper shares this innovative literacy model with its new practices to other African communities and the world, to contribute in minimising the high illiteracy rate reported in various corners of Africa.

CONTACT: Epimaque Niyibizi niyibizi.epimaque1973@gmail.com eniyibizi@yahoo.fr This work is licensed under a Creative Commons Attribution 4.0 International License. 
Volume 2, 2020

\section{Literature review}

\section{Towards the conceptualisation and implementation of the 'Eclectic Traditional Value Hub Model' or 'Four-in-One' Literacy Model'}

As described in the contextual background, this "Eclectic Traditional Value Hub Model" or 'four-in-one' Literacy Model" is an innovative literacy model, which was conceived by a team of lecturers at the University of Rwanda and applied to selected rural communities in Rwanda, with the ultimate goal of accelerating quadriliteracy and community literacy and numeracy among adults with limited literacy in the Rwandan multilingual setting, where four languages are recognised as official languages. The literacy sessions which apply this model focus on the use of those four official languages previously stated, drawing from the African and Rwandan traditional values.

Linked with the existing literature in the world, we observe that a great number of initiatives on literacies are being implemented in different parts of the world, but with paucity of projects or programmes that support adult community literacy in a multilingual setting, particularly in Africa, tackled from African traditional value perspectives. Many African communities, including Rwanda, and other parts of the world, still experience a low level of literacy in the $21^{\text {st }}$ century, within their multilingual settings (Baker, 2006; Iwashita, Brown, McNamara \& O’Hagan, 2008; Niyibizi, Makalela \& Mwepu, 2015; Niyibizi \& Ahimana, 2019).

As a contribution to address this literacy gap, an innovative model coined 'Four Languages in One Literacy Session' or 'Four-in-One Literacy Model' has been implemented in selected Rwandan rural communities to promote community literacy, multiliteracies and digital literacy among adults with limited literacy and numeracy, located in rural areas.

The model is embedded in a four-in-one training toolkit for community literacy, where it is coined in four languages, as indicated in table 1: 
Volume 2, 2020

Table 1: The name of 'Four-in-One Literacy Model' presented in four languages

\begin{tabular}{|c|c|c|c|}
\hline English & French & Kiswahili & Kinyarwanda \\
\hline $\begin{array}{l}\text { "Eclectic } \\
\text { Traditional } \\
\text { Value Hub } \\
\text { Model" Or } \\
\text { "Eclectic } \\
\text { Indangagaciro } \\
\text { Hub Model" For } \\
\text { Community } \\
\text { Literacy And } \\
\text { Numeracy or } \\
\text { "Four in one" } \\
\text { (four-in-one) }\end{array}$ & $\begin{array}{l}\text { Modèle Éclectique } \\
\text { s'inspirant des } \\
\text { Valeurs } \\
\text { Traditionnelles } \\
\text { Rwandaises» Ou } \\
\text { "Modèle de Noyau } \\
\text { Éclectique } \\
\text { Indangagaciro" } \\
\text { Pour } \\
\text { L'alphabétisation } \\
\text { Communautaire" } \\
\text { ou "Quatre en } \\
\text { une" ( } 4 \text { en 1) }\end{array}$ & $\begin{array}{l}\text { Mkusanyiko wa } \\
\text { Ufundishaji } \\
\text { Unaochota } \\
\text { Kwenye } \\
\text { Chemchemu ya } \\
\text { Amali za } \\
\text { Wanyarwanda } \\
\text { Katika } \\
\text { Kufundisha } \\
\text { Lugha, Sayansi } \\
\text { aa Utamaduni » } \\
\text { au " Mkabala } \\
\text { Wenye Asili Ya } \\
\text { Amali Za Kijadi } \\
\text { Indangagaciro } \\
\text { Kwa Ufundishaji } \\
\text { Wa Jumuia" } \\
\text { au "Nne katika } \\
\text { Moja" (4 katika } \\
\text { 1) }\end{array}$ & $\begin{array}{l}\text { Inkomatanyamyigishirize } \\
\text { Ivoma ku Ndangagaciro } \\
\text { Nyarwanda mu Kwigisha } \\
\text { Indimi, Ubumenyi } \\
\text { n'Umuco cyangwa "Enye } \\
\text { muri rumwe" (4 muri 1) }\end{array}$ \\
\hline
\end{tabular}

The literacy practices that are suggested in this model are somehow new, if we compare with the common practices in teaching literacy, and its newness is reflected in the next section.

\section{How "Eclectic Traditional Value Hub Model" or 'four-in-one' Literacy Model" works The "four-in-one Literacy Model" in practice}

This section explains how the "four-in-one literacy model" works and how its training toolkit was designed. First, the training toolkit was designed for Rwandan adults, and the content draws from African and Rwandan traditional cultural practices, which are presented in four languages in parallel position as presented above to enable both vertical and horizontal reading.

Concretely, Volume 1 of the training toolkit, which was used in the pilot phase, is built on African and Rwandan traditional values or cultural values which are known by every adult Rwandan citizen. In this regard, six cultural practices known as 'Imikorongiro' in Kinyarwanda 
Volume 2, 2020

language, which can be translated as 'cultural task-oriented practices' or cultural-based practices', constituted the content and literacy practice for this training toolkit Volume 1.

The content for each of the six cultural practices was developed, and their literacy practices were applied across the four languages. The teaching and learning in all literacy sessions involve all the five big skills for literacy (listening, speaking, reading, writing and viewing), accompanied by digital literacy.

Each unit presents the description of the cultural practice, the embedded sciences and technology as well as cultural values and literary genres such as proverbs, riddles and other literary genres, in four languages. Those literacy practices are presented in four languages, as illustrated in table 2, focusing on reading and writing, in four languages in parallel: 
Table 2: Quadriliteracy practice of 'Four-in-One Literacy Model', with focus on reading and writing

\begin{tabular}{|c|c|c|c|}
\hline Kinyarwanda & English & Kiswahili & French \\
\hline $\begin{array}{l}\text { Twige gusoma no } \\
\text { kwandika } \\
\text { Vuga kandi wandike } \\
\text { inyajwi, ingombajwi } \\
\text { n'ibihekane biri mu ijambo } \\
\text { ribumbye uyu } \\
\text { mukorongiro } \\
\text { « kwizigamira » } \\
\text { Mu ijambo « } \\
\text { kwizigamira », harimo } \\
\text { inyajwi ebyiri (2) : } \\
\text { i-a / I-A } \\
\text { k-w-i-z-i-g-a-m-i-r-a / K- } \\
\text { W-I-Z-I-G-A-M-I-R-A } \\
\text { Ingombajwi } \\
\text { zigaragaramo ni } \\
\text { esheshatu (6) k-w-z-g- } \\
\text { m-r } \\
\text { k-w-i-z-i-g-a-m-i-r-a / K- } \\
\text { W-I-Z-I-G-A-M-I-R-A } \\
\text { Hagaragaramo } \\
\text { igihekane kimwe (1): } \\
\text { kw-I KW- } \\
\text { kw-i-z-i-g-a-m-i-r-a / KW- } \\
\text { l-Z-I-G-A-M-I-R-A }\end{array}$ & $\begin{array}{l}\text { Literacy and } \\
\text { numeracy skills } \\
\text { Say, write and read } \\
\text { all the vowels and } \\
\text { consonants in the } \\
\text { word: "saving" } \\
\text { We have two (2) } \\
\text { vowels: a- i. / A-I } \\
\text { s-a-v-i-n-g / S-A-V- } \\
\text { I-N-G } \\
\text { there are also four } \\
\text { (4)consonants: s- } \\
\text { v-n -g/ S-V- N-G } \\
\text { S-a-v-i-n-g/ S-A-V- } \\
\text { I-N-G }\end{array}$ & $\begin{array}{l}\text { Tujifunze } \\
\text { kusoma na } \\
\text { kuandika } \\
\text { Bainisha na } \\
\text { uandike irabu na } \\
\text { konsonanti } \\
\text { ambazo } \\
\text { hujitokeza katika } \\
\text { maneno } \\
\text { "Uhifadhi mali” } \\
\text { kuna irabu } \\
\text { tatu: } \\
\text { u-i-a / U-I-A. } \\
\text { u-h-i-f-a-d-h-i } \\
\text { m-a-I-i / U-H-I- } \\
\text { F-A-D-H-I M-A- } \\
\text { L-I. } \\
\text { Kuna } \\
\text { konsonanti 5: } \\
\text { h-f-d-m-I/ H-F- } \\
\text { D-M-L }\end{array}$ & $\begin{array}{l}\text { Apprenons à lire } \\
\text { et à écrire } \\
\text { Lis et écris les } \\
\text { voyelles et les } \\
\text { consonnes que } \\
\text { contient le mot } \\
\text { « épargne ». } \\
\text { Il y a trois (3) } \\
\text { voyelles écrites } \\
\text { en minuscule } \\
\text { voire en } \\
\text { majuscule : E-a-e } \\
\text { / E-A-E } \\
\text { E-p-a-r-gn-e/ E- } \\
\text { P-A-R-GN-E } \\
\text { Les consonnes } \\
\text { qui s'y trouvent } \\
\text { sont au nombre } \\
\text { de quatre (4): } \\
\text { P-r-g-n / P-R-G-N } \\
\text { E-p-a-r-gn-e/ E- } \\
\text { P-A-R-GN-E }\end{array}$ \\
\hline
\end{tabular}


Volume 2, 2020

Table 2 shows how trainees acquire reading and writing vowels and consonants in four languages, based on the cultural practice of 'Saving'. Another example in Table 3 focuses on developing vocabulary in four languages:

Table 3: Quadriliteracy practice of 'Four-in-One Literacy Model', with focus on vocabulary

\begin{tabular}{|c|c|c|c|}
\hline Kinyarwanda & English & Kiswahili & French \\
\hline $\begin{array}{l}\text { Twige } \\
\text { inyunguramagambo } \\
\text { n'inshoberamahanga } \\
\text { Soma kandi wandike } \\
\text { amagambo } \\
\text { akurikira: } \\
\text { 1.Ikigega/ umutiba } \\
\text { 2. kwizigamira } \\
\text { 3. Banki } \\
\text { 4. Ibigo by'imari } \\
\text { iciriritse } \\
\text { 5. Ibigo byo kubitsa no } \\
\text { kugurizanya / SACCO }\end{array}$ & $\begin{array}{l}\text { Read and write } \\
\text { the following } \\
\text { words: } \\
\text { 1. Granary/ loft } \\
\text { 2. Saving } \\
\text { 3. Banks } \\
\text { 4. Micro finance } \\
\text { 4. Saving and } \\
\text { credit cooperatives } \\
\text { (SACCO) } \\
\text { 5. Community work }\end{array}$ & $\begin{array}{l}\text { Soma na uandike } \\
\text { maneno } \\
\text { afuatayo: } \\
\text { 1. Ghala } \\
\text { 2. Kujihifadhia mali } \\
\text { 3. Benki } \\
\text { 4. Hazina } \\
\text { 5. Mashirika ya } \\
\text { Akiba na Mikopo } \\
\text { (SACCO) }\end{array}$ & $\begin{array}{l}\text { Enrichissons et } \\
\text { approfondissons nos } \\
\text { vocabulaires et } \\
\text { expressions } \\
\text { Lis et écris les mots } \\
\text { suivants: } \\
\text { 1. Grenier } \\
\text { 2. Epargne } \\
\text { 3. Banque } \\
\text { 4. Microfinance } \\
\text { 5. Coopérative de crédit } \\
\text { et d'épargne/ SACCO }\end{array}$ \\
\hline
\end{tabular}

CONTACT: Epimaque Niyibizi niyibizi.epimaque1973@gmail.com eniyibizi@yahoo.fr This work is licensed under a Creative Commons Attribution 4.0 International License. 
Volume 2, 2020

The exercise in table 3 encourages the trainees to read and jot down new words they learned in four languages, based on the cultural practice of 'Saving'. This practice enables them to compile important vocabulary, which they need to use in their daily business.

In a nutshell, the "Eclectic Traditional Value Hub Model" or "four-in-one Literacy Model" works in a way that supports adults who need basic literacy in four languages to enhance them comprehensively.

\section{Code-switching, cross-lingual practices and code-translation in "four-in-one Literacy Model"}

While the "four-in-one Literacy Model" is crossing between four official languages used in Rwanda, namely Kinyarwanda, English, French and Kiswahili, it relied mainly on intersentential switching or code-switching, and not on intra-sentential switching or codemixing. Code-switching is described as the alternation of two or more languages in a speaker's speech at the word, phrase or clause, sentence, and discourse or paragraph level (Myers-Scotton, 1993; Moodley and Kamwangamalu, 2004; Moodley, 2013). The application of code-switching in our 'Four-in-One Literacy Model' followed the difference between intersentential code-switching and intrasentential code-switching, as suggested three decades ago by Bokamba (1985) and UNISA (1997). In this regard, Bokamba (1985) viewed codeswitching as consisting of two distinct phenomena: intersentential switching or code-switching and intrasentential switching or codemixing. This led to Bokamba's definition of code-switching as "embedding or mixing words, phrases and sentences from two codes within the same speech event and across sentence boundaries" (Bokamba, 1985, p.13). The expanded definition of code-switching is "the alternate use of two or more languages or varieties in a single communicative episode or in distinct social or functional domains" (UNISA, 1997, p.200).

Hence, our four-in-one Literacy model applied intersentential code-switching, which promoted alternation of English, French, Kinyarwanda and Kiswahili sentences, not within the sentence but beyond the sentence and the paragraph. Such practices were more related to codetranslation and cross-lingual practices. Horizontal reading across the four languages emphasised such practices. However, our model discouraged codemixing or intrasentential switching, which consists of alternating languages or codes within the sentence. We opted for this strategy to minimise confusion among the trainees. Reading one sentence language one, and then read its equivalent in language two, in language three and then in language four was found more appropriate for people with limited proficiency in those four languages. Hence, 'Four-in-One Literacy Model' consisted of developing literacy in language one (Kinyarwanda) for 15 minutes; then switch to a similar practice in language two (English) for another 15 minutes, and then switch to a similar practice in language three (Kiswahili) for the next 15 minutes, and lastly switch to language four (French) for the last 15 minutes. With such practices, the similar content is covered in four languages within one lesson of 60 minutes,

CONTACT: Epimaque Niyibizi niyibizi.epimaque1973@gmail.com eniyibizi@yahoo.fr

This work is licensed under a Creative Commons Attribution 4.0 International License. 
Volume 2, 2020

using intersentential code-switching or code-alternation or cross-lingual practices as mentioned above.

\section{Methodology: Implementation of 'four-in-one' Literacy model and assessment for its effectiveness}

This methodology section highlights the process of ' 4 in 1 literacy model' implementation, which is detailed in five steps, as well as the training sites and the participants. Indeed, the essence of 'Four-in-One Literacy Model' was conceptualised from a deep analysis of literacy and numeracy practices in Rwanda, particularly for the needs of Rwandans to effectively use the 4 official languages and the promotion of technology in adult education and in business. A deep analysis signals that the normal teaching of literacy and numeracy in Rwanda were providing answers that tended to be too superficial to be instrumental, too artificial to be pragmatic, and, on top of that, they usually focus on one language at a go. This 'Four-in-One Literacy Model' initiates methods of practising four languages altogether.

The four-in-one model stemmed from a literacy project which started in rural communities of one district of Rwanda, specifically in Eastern Province, where the University of Rwanda College of Education is located. Eight literacy sites were established in various rural communities, where more than ten thousand community members expressed need to improve their literacy levels, in four official languages used in Rwanda. So far, the model has been implemented for one and a half year (July 2018-December 2019), and this paper explores its level of success in accelerating quadriliteracy and community literacy and numeracy in those four languages. Stakeholders in this literacy project include University of Rwanda - College of Education's lecturers who initiated this innovative literacy model, graduates from secondary schools who are literacy trainers in their local communities, and trainees (adult people) who are citizens with limited literacy like motorists, street vendors, small-sized business people and any other citizens who strive to uplift their illiteracy levels in four languages. The following are methodological steps that were used in implementing the innovative literacy project:

Step 1: Survey for needs analysis

The team of 8 lecturers from the University of Rwanda - College of Education conducted a needs analysis survey, where field visits and interviews and questionnaires were conducted among potential trainees and local leaders, to identify the literacy level in Kinyarwanda, French, English and Kiswahili among the targeted population.

Step 2: Designing the training toolkit and the training content based on the literacy level identified in the initial survey

The content developed in the training toolkit Volume 1 is built on African and Rwandan traditional values or cultural values, which are known by every adult Rwandan citizen.

CONTACT: Epimaque Niyibizi niyibizi.epimaque1973@gmail.com eniyibizi@yahoo.fr

This work is licensed under a Creative Commons Attribution 4.0 International License. 
Volume 2, 2020

Step 3: Massive training of the community literacy trainers.

Here we trained more than 180 High School leavers, who were living in the communities, while they were preparing to join universities and institutions of higher learning. They were assisted by the existing adult literacy trainers and students from the University of Rwanda - College of Education, who were joining them in their communities after class and during the weekend.

Step 4: Conducting actual literacy sessions in the communities, using 'four-in-one literacy model.'

Training sessions were taking place in the evening and over the weekend when citizens were free from their daily activities. The training sites were not necessarily schools, but rather any place in the community where citizens could gather and learn. People of all ages were allowed to attend, except school children who were attending mainstream education.

Step 5: Assessment followed by the survey to check the effectiveness of 'four-in-one literacy model.'

As proficiency in language is manifested through practices, assessment was based on letting citizens perform sketches, scenarios in four languages, in front of the audience, in their communities. This was adding to a progressive assessment that was conducted along with the training. In addition, 60 participants filled in the survey questionnaires and they were interviewed in groups, in the four languages in which they were trained. The next section presents the findings from those interviews and assessments on the effectiveness of the 'Fourin-One Literacy Model'.

\section{Key findings from "Four-in-One Literacy Model"}

\section{Effectiveness and newness of "Eclectic Traditional Value Hub Model" or "Four-in-One Literacy Model"}

Based on the survey and assessment of the effectiveness of the model, the newness and effectiveness of this model are threefold: firstly, it boosts literacy practices in four languages in parallel, namely Kinyarwanda, English, French and Kiswahili, which is described as "Four languages in one literacy session" or "Four in One". Secondly, it draws from a range of African and Rwandan traditional values. Thirdly, it pairs the commonly practised reading mode known as 'vertical monolingual reading' (i.e. reading in one language from the top to the bottom of the page) with 'horizontal reading' or 'horizontal literacy', where one sentence or a paragraph is read in four languages horizontally. Another innovation is that all the five big skills in literacy practices, namely speaking, listening, writing, reading and viewing are practised simultaneously in one language, and consecutively in four languages.

CONTACT: Epimaque Niyibizi niyibizi.epimaque1973@gmail.com eniyibizi@yahoo.fr

This work is licensed under a Creative Commons Attribution 4.0 International License. 
Volume 2, 2020

\section{Effectiveness of 'Four-in-One Literacy Model' in promoting quadriliteracy among rural community members}

The 'four-in-one' model was initially designed for 18 months, with six months for developing training toolkits and training the literacy trainers and eight months for practical literacy sessions with citizens with limited literacy in the selected rural communities. As the participants reported, the positive impact of the model can now be observed. Beneficiaries, communities and the Rwandan society at large has benefited from this innovative literacy project. Positive changes can now be demonstrated through practical performance in four languages which were recorded and shared on YouTube, together with pictures and videos displayed below. They serve as evidence for practical literacy events that took place in Rwandan rural communities.

\subsubsection{Massive quadriliteracy trainers for the community}

The pictures below show the lecturers from the University of Rwanda introducing the 'four-in-one' model to participants who were to conduct literacy sessions in their communities, in various rural villages.
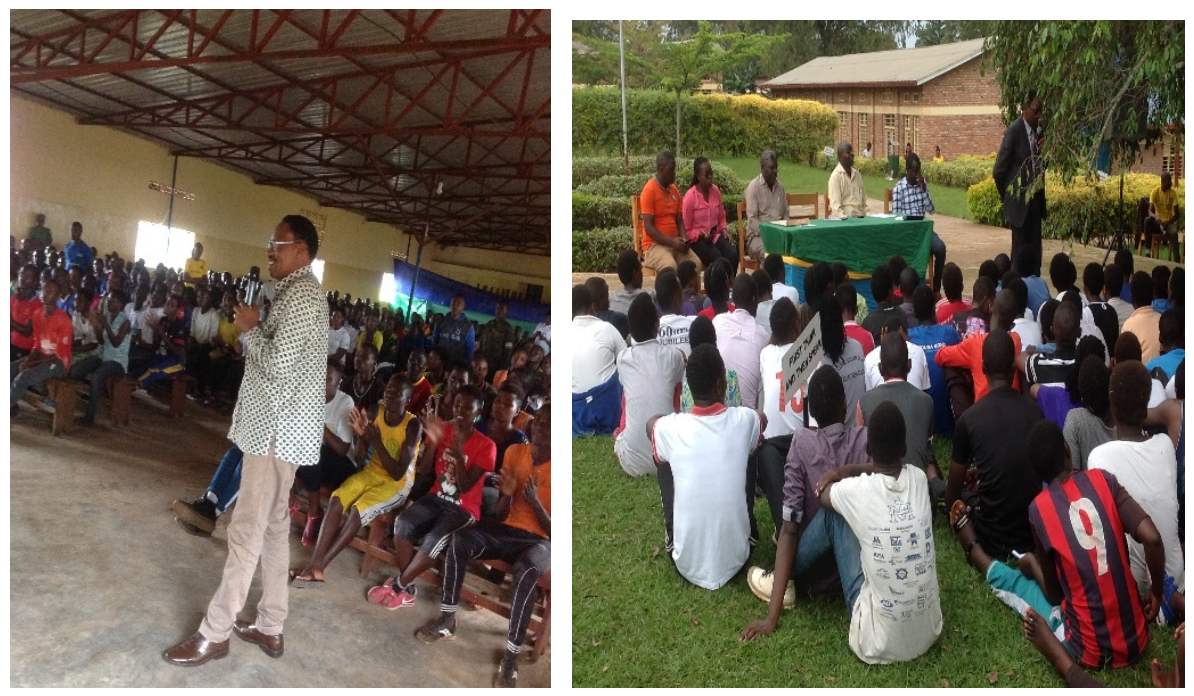

CONTACT: Epimaque Niyibizi niyibizi.epimaque1973@gmail.com eniyibizi@yahoo.fr This work is licensed under a Creative Commons Attribution 4.0 International License. 
Volume 2, 2020

Using a cascade approach, the University lecturers trained master trainers of adult literacy, who were to go to various communities to train other trainers (the youths in the pictures above, who completed senior six or secondary school cycle, who were to train citizens in four languages.
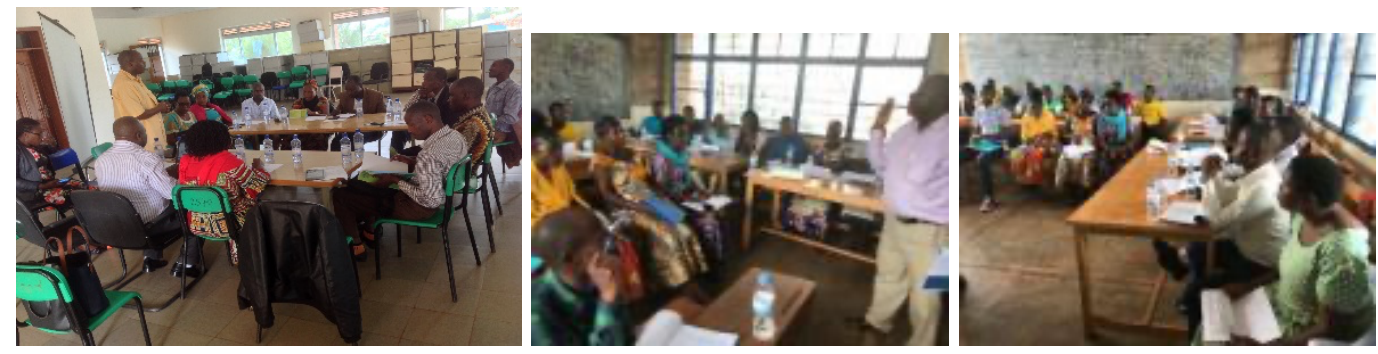

Adult literacy Trainers in Kayonza District, Eastern Province of Rwanda, were trained on the Innovative approach coined "four-in-one" and "Eclectic Traditional Value Hub Model" for Community Literacy and numeracy, in February 2019.

By the end of the training, the master trainers of adult literacy were familiar with the 'four-inone' literacy model, ready to start the activities of boosting literacy among the rural community members.
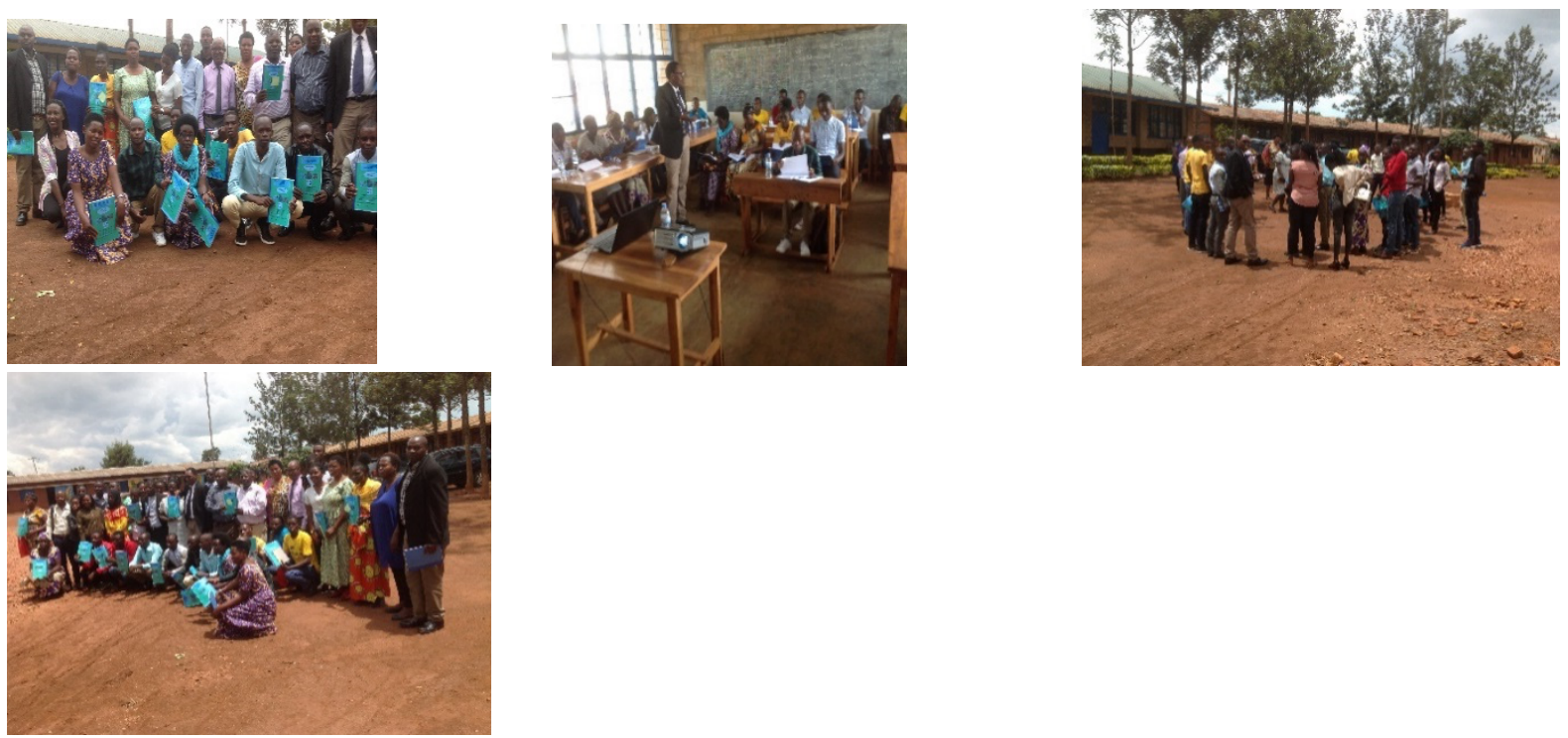

CONTACT: Epimaque Niyibizi niyibizi.epimaque1973@gmail.com eniyibizi@yahoo.fr This work is licensed under a Creative Commons Attribution 4.0 International License. 
Volume 2, 2020

Every master trainer was given a 'four-in-one' training toolkit, which is a training manual written in four languages in parallel, with guidance on horizontal reading, which is reading across the four languages.

\subsubsection{Effectiveness of 'Four-in-One Literacy Model' in training adults with various age ranges in rural communities}

The pictures below show how the project is being implemented in various sites, in rural communities of Rwanda
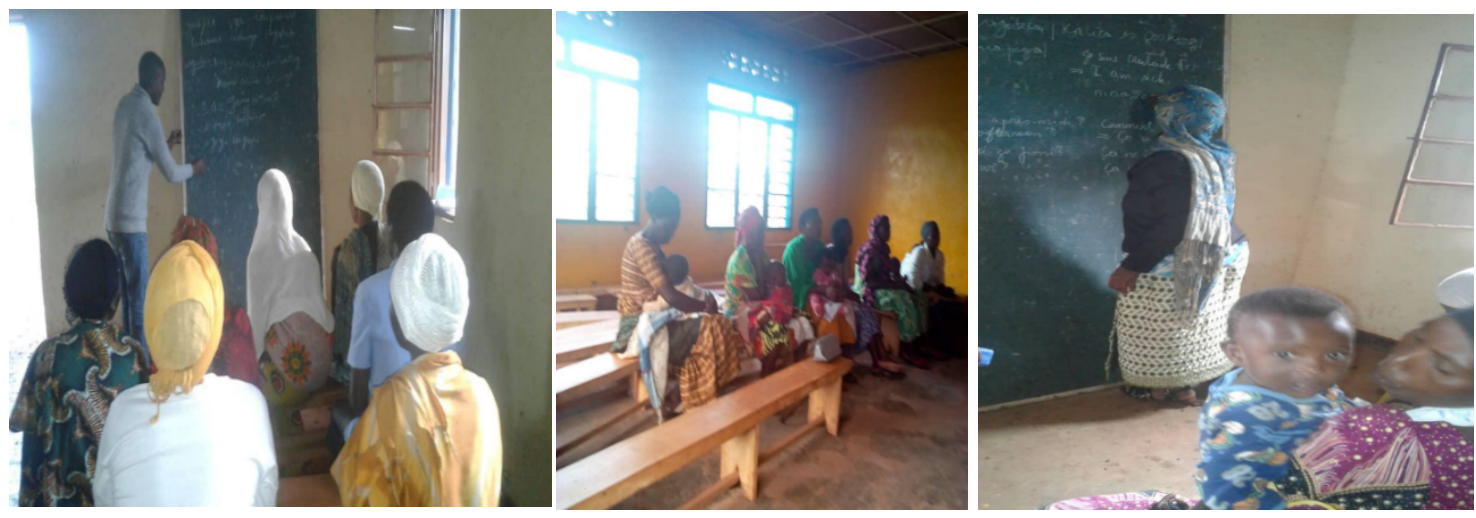

Adult people attending literacy classes in various sites in their respective communities in rural areas of Eastern Province of Rwanda are highly motivated. They even come with their babies to attend literacy classes.

The sample of pictures shows adult people attending literacy classes in various sites in their respective communities in rural areas of Eastern Province of Rwanda. They were so highly motivated that some of them even attended with their babies. This is one of the indicators of the innovated model. Beneficiaries acknowledge the value of adult literacy programmes in improving their socio-economic status.

The participants reported that the 'four-in-one' literacy practices were effective, efficient, relevant and pertinent in boosting community literacy. Statistics on the number of trainees reveals that female participants outnumbered male participants, even if equality is our guiding principle. However, this can be justified on one side by the fact that the majority of Rwandans are women, and on the other side by the fact that due to traditional beliefs, from the time modern education was introduced in Rwanda, priority in attending school was given to more boys than girls.

The model served as an alternative vehicle of literacy and numeracy for different categories of beneficiaries who had missed out the mainstream education system. People aged between 15 and 30 years and beyond, actively attended the training. Some of these young people were

CONTACT: Epimaque Niyibizi niyibizi.epimaque1973@gmail.com eniyibizi@yahoo.fr

This work is licensed under a Creative Commons Attribution 4.0 International License. 
Volume 2, 2020

those who had not gone to school in their early years. Their major concern was the inability to read and write anything even in their mother tongue, the language in which they did not have any difficulty in listening and speaking. The 'four-in-one' Literacy model helped them to develop writing and reading skills of Kinyarwanda. This category includes farmers, vendors, masons, motorcyclists and bicyclists who had limited numeracy skills and limited literacy in Kinyarwanda, English, French and Kiswahili. The innovated model enabled them to learn and increase their proficiency in those languages depending on individual needs in their job practices.

Similarly, the middle-aged and old people benefited from the 'four-in-one' Literacy model since it helped them to acquire reading and writing skills in Kinyarwanda, and basic listening and speaking skills in English, French and Kiswahili. They reported that they are now able to communicate with other people as some of them conduct their business operations in and outside the country with users of different languages.

In brief, the 'four-in-one' Literacy model is a language teaching and learning innovation that favours the achievement of SDGs, especially goal three which emphasises the promotion of well-being for all at all ages- and goal four which stresses the promotion of lifelong learning opportunities for all (United Nations, 2019).

\subsubsection{Effectiveness of 'Four-in-One Literacy Model' in promoting digital literacy among rural community members}

The 'four-in-one' literacy model promoted digital literacy through the use of cell phones, all along the training process, especially in doing homework. Through the testimonies provided by different trainees, it was reported that the trainees are now able to send text messages with their cell phones as one part of literacy practices. They reported that this literacy practice helped them to develop reading and writing on mobile phone screens and general comprehension skills. They are now familiar with literacy and numeracy practice as they send and receive texts mixed with numbers and share them with their colleagues at a distance. This shows that cell phones have supported these adult people not only in interacting with other citizens but also to practice and sustain their literacy and numeracy skills. This is in line with arguments from scholars like Muyinda (2010) and Lankshear and Knoel (2011) that mobile phones have been recognised as a potential tool in boosting learning opportunities since these devices are mostly used in text and voice communication, file transfer, internet access among other functions related to learning resources. Similarly, Khaddage and Knezek (2013) indicated that mobile phones are believed to be not only connecting people socially but also supporting learning activities in different formal and non-formal learning practices. Our 'fourin-one' literacy model also contributed to the promotion of digital literacy practices. The practical evidence is the homework presented in Table 4:

CONTACT: Epimaque Niyibizi niyibizi.epimaque1973@gmail.com eniyibizi@yahoo.fr

This work is licensed under a Creative Commons Attribution 4.0 International License. 
Volume 2, 2020

Table 4: Quadriliteracy practice of 'Four-in-One Literacy Model', with a focus on digital literacy

\begin{tabular}{|c|c|c|c|}
\hline Kinyarwanda & English & Kiswahili & French \\
\hline $\begin{array}{l}\text { Umukoro: } \\
\text { D.Ukoresheje } \\
\text { terefone yawe } \\
\text { cyangwa ikaramu } \\
\text { n'urupapuro } \\
\text { k'udafite terefone, } \\
\text { andika inyajwi, } \\
\text { ingombajwi } \\
\text { n'ibihekane twize } \\
\text { ubyoherereze } \\
\text { mugenzi wawe kuri } \\
\text { terefone ye azisome } \\
\text { aranguruye ijwi. }\end{array}$ & $\begin{array}{l}\text { Homework } \\
\text { exercise: } \\
\text { D. Using your } \\
\text { mobile phone or } \\
\text { pen and paper (for } \\
\text { those without } \\
\text { phones) write all } \\
\text { vowels and } \\
\text { consonants you } \\
\text { know and send } \\
\text { them to a } \\
\text { colleague to read } \\
\text { aloud. }\end{array}$ & $\begin{array}{l}\text { Zoezi: } \\
\text { D. Kwa kutumia simu } \\
\text { yako ya mkono ama } \\
\text { kalamu na karatasi } \\
\text { (kwa wale wasiokuwa } \\
\text { na simu) andika irabu } \\
\text { na konsonanti } \\
\text { tulizokwishajifunza } \\
\text { halafu zitume kwa } \\
\text { mwenzako kwa njia ya } \\
\text { simu ya mkono. }\end{array}$ & $\begin{array}{l}\text { Exercices à } \\
\text { domicile: } \\
\text { D. A l'aide de ton } \\
\text { téléphone ou bien } \\
\text { d'un morceau de } \\
\text { papier, écris des } \\
\text { voyelles ainsi que } \\
\text { des consonnes } \\
\text { que nous venons } \\
\text { de voir et envois- } \\
\text { les à ton collègue. }\end{array}$ \\
\hline
\end{tabular}

Source: Training toolkit Volume 1 (March 2020)

The exercise in Table 4 shows that the trainees were doing some home assignments on literacy, where they could write and send to trainers and receive feedback via mobile phones.

\section{Effectiveness of 'Four-in-One' Literacy Model in promoting numeracy and basic science skills among rural community members}

One of the innovations of the 'four-in-one' literacy model was to promote numeracy among community members with limited numeracy skills. The first beneficiaries of the 'four-in-one' model were the secondary school leavers who were trainers in their respective villages and communities. They were training other citizens in quadriliteracy, but most of them were candidates to Universities and higher learning institutions, including those who were to follow Sciences, Technology and Mathematics (STEM). Hence, the youths benefited from the 'fourin-one' model outputs by participating in language and STEM-related practices that aimed at promoting numeracy in their surrounding community and thus demystifying the commonly held belief that there is no close relationship between language mastery and STEM subject teaching and learning. The content in all units of the training toolkit was designed in such a way every cultural practice was reflecting Mathematics, Physics, Biology, Chemistry and ICT components embedded in that particular Rwandan / African cultural practice.

As an illustrative example, in the traditional practice of saving as a culture to secure Rwandans bright future, there is a drawing of a traditional granary, which embedded mathematics, science and technology as follows: 
Volume 2, 2020

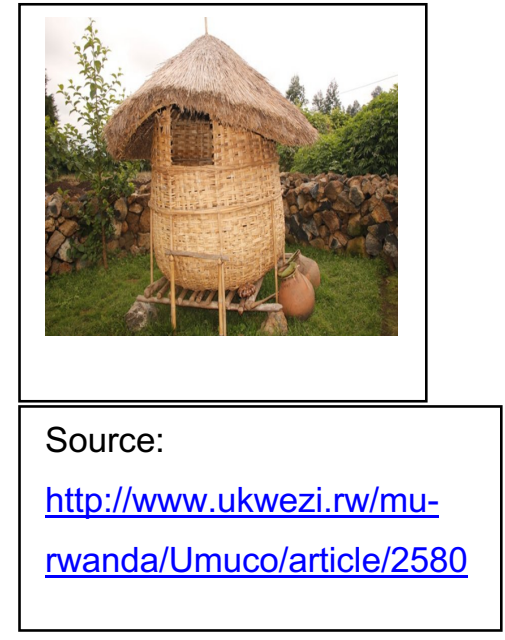

- Mathematics: (Algebra): In the construction process of a granary, they used to fix vertical pieces of trees playing role of pillars, with other horizontal pieces of trees, which were cutting across. On the top of the granary, they fixed an antenna like the one of a traditional house. A granary used to have a form or a shape of a cylinder with vertical and horizontal pillars representing columns and rows for teaching matrices. An antenna of that granary used to have an axis of symmetry. In addition, they used the measurement units for volume to fill up the granary with harvest (sorghum, beans or maize).

- Physics: The granary was built in a stable way (preserved equilibrium), and the slope of its roof was constructed in such a way that it eased the flow of rainwater (slope /inclination). The antenna of a granary was similar to a lightning rod and was the centre of gravity to which roofing was fixed.

- Chemistry: they used ash as an insecticide to conserve the harvest.

With this traditional practice, for example, numeracy skills in mathematics and other sciences are taught to participants.

They are even given numeracy homework activities, as illustrated with examples in Table 5. 
Volume 2, 2020

Table 5: Quadriliteracy practice of 'Four-in-One Literacy Model', with focus on numeracy

\begin{tabular}{|c|c|c|c|}
\hline Kinyarwanda & English & Kiswahili & French \\
\hline $\begin{array}{l}\text { Tumenye gukoresha } \\
\text { neza igishoro } \\
\text { n'igicuruzo no } \\
\text { kubara neza inyungu } \\
\text { n'igihombo. } \\
1 . \text { Shema yaranguye } \\
\text { ibiro } 20 \text { (20 kg) } \\
\text { by'ibirayi ku } \\
\text { mafaranga } 150 \text { ku } \\
\text { kiro. Ageze ku isoko } \\
\text { Ngabo } \\
\text { arabimugururira ku } \\
\text { mafaranga } 180 \text { ku } \\
\text { kiro. Ubwo Shema } \\
\text { yungutse amafaranga } \\
\text { angahe? } \\
\text { Nyuma y'uyu } \\
\text { mukoro tuzirikane } \\
\text { ko: } \\
\text { Inyungu/igihombo= } \\
\text { Igicuruzo gukuramo } \\
\text { igishoro (Igicuruzo- } \\
\text { Igishoro) } \\
\text { lgicuruzo= Igishoro } \\
\text { kongeraho inyungu } \\
\text { (Igishoro+inyungu) }\end{array}$ & $\begin{array}{l}\text { Learning } \\
\text { about the } \\
\text { capital and } \\
\text { calculating } \\
\text { interest or } \\
\text { profit and } \\
\text { loss } \\
\text { 1) Shema } \\
\text { bought } 20 \mathrm{kgs} \\
\text { of potatoes at } \\
\text { the price of } \\
\text { 150 Frw per } \\
\text { 1kg. When he } \\
\text { reached in his } \\
\text { village, he sold } \\
\text { the potatoes to } \\
\text { Ngabo at } 180 \\
\text { Frw per } 1 \mathrm{~kg} . \\
\text { How much } \\
\text { money did } \\
\text { Ngabo get } \\
\text { after selling } \\
\text { his potatoes? } \\
\text { What is } \\
\text { Shema's } \\
\text { profit? } \\
\text { Note that: } \\
\text { The profit or } \\
\text { loss = Sell- } \\
\text { Capital } \\
\text { Sell= Capital+ } \\
\text { profit }\end{array}$ & $\begin{array}{l}\text { Tujue kutumia } \\
\text { vizuri } \\
\text { kitegauchumi, } \\
\text { kuhesabu vizuri } \\
\text { faida na hasara. } \\
\text { Tujue pia } \\
\text { uhusiano kati ya } \\
\text { kitegauchumi, } \\
\text { faida na hasara. } \\
\text { 1) Shema } \\
\text { alinunua kilo } \\
\text { ishirini za viazi } \\
\text { mviringo kwa bei } \\
\text { ya } 150 \text { Frw/1kg. } \\
\text { Wakati alipofika } \\
\text { sokoni Ngabo } \\
\text { anavichua vyote } \\
\text { kwa bei ya } \\
\text { 180Frw/1kg. } \\
\text { Baada ya kuuza } \\
\text { viazi mviringo, } \\
\text { hifadhi ya Shema } \\
\text { ni pesa ngapi ? } \\
\text { Faida yake ni } \\
\text { pesa ngapi ? } \\
\text { Baada ya zoezi } \\
\text { hili tutilie } \\
\text { maanane } \\
\text { hasara= mapato- } \\
\text { kitegauchumi= } \\
\text { faida /hasara C2- } \\
\text { C1 }\end{array}$ & $\begin{array}{l}\text { Apprenons à bien } \\
\text { utiliser le capital, à } \\
\text { bien vendre, à bien } \\
\text { calculer le bénéfice et } \\
\text { les pertes si il y en a. } \\
\text { Le rapport entre le } \\
\text { capital, le bénéfice/ } \\
\text { gain ou profit et les } \\
\text { pertes. } \\
\text { 1) Shema a acheté } 20 \\
\text { kilos (20 kg) de pommes } \\
\text { de terre à } 150 \text { Frw le kg. } \\
\text { Arrivé au marché, il les a } \\
\text { vendus à Ngabo à } \\
\text { 180Frw le Kilo. Shema } \\
\text { a-t-il fait le bénéfice de } \\
\text { combien d'argent? } \\
\text { Après l'exercice de } \\
\text { cette pratique, il est à } \\
\text { savoir que le } \\
\text { gain/profit/bénéfice(B) } \\
\text { ou la perte (P) est la } \\
\text { différence entre le prix } \\
\text { d'achat (PA) et le prix } \\
\text { de vente(PV) : PA- } \\
P V=B / P\end{array}$ \\
\hline
\end{tabular}

Source: Training toolkit Volume 1

CONTACT: Epimaque Niyibizi niyibizi.epimaque1973@gmail.com eniyibizi@yahoo.fr

This work is licensed under a Creative Commons Attribution 4.0 International License. 
Volume 2, 2020

The example in Table 5 shows how the 'four-in-one' literacy model provided take-home assignments, where participants could read, do calculations from their homes and send the answers to the trainers by mobile phones.

\section{Key challenges reported in the implementation of 'four-in-one model' on various sites}

The practices, the opportunities and challenges in implementing the 'four-in-one' literacy model were reported by the participants on the four training sites where the model was piloted in the first year of implementation. On site one, the literacy training applying 'four-in-one' model was appreciated by local leaders. Citizens of this locality were very happy about the model and a big number of youths, adults and old people were enrolled and attended showing a great interest. Participants reported that the training in this new and innovative practice enabled them to simultaneously practice four languages orally and in writing as well as via their mobile phones. They reported that it helped them to cope with daily basic communication needs.

Regarding challenges encountered while dealing with quadrilingual literacy practice on site two, participants reported that the first volume of 'four-in-one' training toolkit seemed not to be at the level of all literacy and numeracy beneficiaries. This is due to the fact that they are not at the same literacy level while the toolkit is at average level. Most of them were learning at a slower pace, and some of them had poor retention capacity in practicing four languages concurrently. Furthermore, the trainers claimed that they tended to cherish some languages over others. For example, they unconsciously tended to allocate less time to French than other three languages.

On site two, site three and site four, the teaching of literacy and numeracy through 'four-inone' model was also appreciated by adult learners, who attended eagerly to learn and improve their skills in literacy and numeracy. Some trainees had zero literacy and numeracy in writing even in Kinyarwanda, which is their mother tongue. Others had no single knowledge in French, English and Kiswahili, and it was challenging to train them at the same pace, with the same results in literacy. The number of trainees changed daily. Sometimes the number increased and then reduced on the next day. They explained that this was caused by the fact that the population in the area has no permanent jobs and earns their daily lives after working for others. Hence, they sometimes work far away from the training site and then fail to attend the sessions on some days.

The general challenge which was reported from all the training sites is the limited number of training toolkits compared to the number of trainees. Trainees were sharing the materials, which limit their practices at home. It was not easy to print sufficient copies of the training toolkits due to limited project funds, with a large number of participants.

CONTACT: Epimaque Niyibizi niyibizi.epimaque1973@gmail.com eniyibizi@yahoo.fr

This work is licensed under a Creative Commons Attribution 4.0 International License. 


\section{Conclusion and recommendations}

The model has been piloted for one and a half year, and there is a need to apply it to another setting, on an extended area. It has been implemented in Rwanda, and this paper recommends extending this quadriliteracy model to other African countries with multilingual settings. Such a move can contribute in minimising the high illiteracy rate reported in various corners of Africa not only in their mother tongues but also in foreign language used in different countries, particularly the official ones.

Similarly, applying 'four-in-one' Model requires increasing time and duration of the training and moving according to the learning pace of trainees. Pairing trainers with various levels of proficiency in French, English, Kiswahili and Kinyarwanda was an opportunity to practice among themselves. This multi-level toolkit opened the door for community literacy that accommodates all citizens and group them not according to their respective literacy levels, but according to their willingness to improve their literacy in four languages. As education is a master key for development, we believe that applying 'four-in-one' literacy model in Rwanda, in Africa and in other parts of the world may contribute in minimising illiteracy and uplifting citizens' economy. Depending on the number of official languages in each particular country, they can apply 'Five-in-one', 'Three-in-one' or 'Two-in-one Literacy Model' in different parts of Africa and beyond.

\section{Acknowledgments}

We are grateful to the University of Rwanda's Centre for Innovation and Entrepreneurship which funded our project and the University of Rwanda- College of Education, which enabled us to present this paper at DETA Conference in Nigeria in July 2019. We acknowledge the contribution of Kayonza District community members in Rwanda, who attended the training, their trainers, their community local leaders who participated in the project and accepted to provide the useful data that significantly yielded the findings of this paper.

\section{References}

Baker, C. 2006. Foundations of bilingual education and bilingualism. Fourth edition. Clevedon: Multilingual Matters.

Fretwell, D.H. \& Colombano, J.E. 2000. Adult continuing education: an integral part of lifelong countries. Emerging policies and programs for the $21^{\text {st }}$ Century in upper and middle countries. World Bank Discussion Paper. Washington, D.C.: The World Bank.

Iwashita, N., Brown, A., McNamara, T., \& O'Hagan, S. 2008. Assessed Levels of Second Language Speaking Proficiency: How Distinct? Applied Linguistics, 29 (1), 24-49.

CONTACT: Epimaque Niyibizi niyibizi.epimaque1973@gmail.com eniyibizi@yahoo.fr

This work is licensed under a Creative Commons Attribution 4.0 International License. 
Volume 2, 2020

Khadagge, F. \& Knezek G. 2013. I learn via mobile phone technology: A comparison of Mobile learning attitudes among University Studies in two Nations. Proceedings of the IEEE 13th International Conference on Advance Learning Technologies. Beijing, China.

Lankshear, C., \& Knobel, M. 2008. Digital literacies: Concepts, policies, and practices. London: Peter Lang.

Makalela, L. 2015. New directions in language and literacy education for multilingual classrooms in Africa. Cape Town: The Centre for Advanced Studies of African Society (CASAS).

MINECOFIN (Ministry of Finance and Economic Planning). 2005. A synthesis of the analyses of the 2002 census of Rwanda: third population and housing census in Rwanda, 15 Aug 2002. National Census Service. Kigali, Rwanda.

MINECOFIN (Ministry of Finance and Economic Planning). 2014. Fourth Population and Housing Census, Rwanda, 2012: Thematic Report: Education characteristics of the population. National Institute of Statistics of Rwanda, Kigali, Rwanda.

MINEDUC (Ministry of Education). 2018. 2017 Educational Statistical Year Book. Kigali, Rwanda.

Munyankesha, P. 2004. Les Défis du Plurilinguisme Officiel au Rwanda. Analyse Sociolinguistique. PhD thesis. The University of Western Ontario, Canada.

Muyinda, B. P. 2010. Deploying and utilising learning objects on mobile phone. Kampala: Makerere University.

Niyibizi, E., Makalela, L. \& Mwepu, D. 2015. Language-in-education policy shifts in an african country: colonial confusion and prospects for the future. In Leketi Makalela (Ed.). New Directions in Language and Literacy Education for Multilingual Classroom in Africa, pp.97-118. Cape Town: The Centre for Advanced Studies of African Society (CASAS).

Niyibizi, E. \& Ahimana, E. 2018. Literacy Trajectories in African Languages and English: Comparative Exploration among Rwandan, Malawian and Zambian Learners. Sembura Ferment littéraire, 1 (1):198-210.

Niyibizi, Sibomana, Niyomugabo, Yanzigiye, Amini-Ngabonziza \& Perumal. 2018. Assessment in a Rwandan higher education institution: a quest for aligned assessment to promote socio-economic transformation. Assessment \& Evaluation in Higher Education, 43:7, 1166-1182, DOI: 10.1080/02602938.2018.1436688.

CONTACT: Epimaque Niyibizi niyibizi.epimaque1973@gmail.com eniyibizi@yahoo.fr This work is licensed under a Creative Commons Attribution 4.0 International License. 
Volume 2, 2020

Niyibizi, E., Sibomana, E. \& Perumal, J. 2019. Learning to teach writing through distance education programme: Experience with Rwandan high school English teachers. Reading and Writing 10 (1), a206. DOI: htps://doi.org/10.4102/rw.v10i1.206

Rosendal, T. 2009. Linguistic markets in Rwanda: language use in advertisements and on signs. Journal of Multilingual and Multicultural Development, 30 (1), 19-39.

Samuelson, B. L. \& Freedman, S. W. 2010. Language policy, multilingual education, and power in Rwanda. Language Policy,9, 191-215.

Seligmann, J. 2012. Academic literacy for education students. Cape Town: Oxford University Press Southern Africa Ltd.

Sibomana, E. 2010.the acquisition of English as a second language in Rwanda: Challenges and promises. Rwandan Journal of Education, 2 (2). http://www.ukwezi.rw/murwanda/Umuco/article/2580, accessed 17 April 2020.

United Nations. 2019. Report on the progress towards the Sustainable Development Goals. UN Economic and Social Council, p. 8-11. http://minaloc.gov.rw, accessed 15 September 2019. 